\title{
Parasites prevalence which infecting freshwater fishes in Mulur Reservoir of Sukoharjo District, Indonesia
}

\author{
AHMAD HUSEIN IRIANSYAH, AGUNG BUDIHARJO ${ }^{\boldsymbol{\nu}}$, SUGIYARTO \\ Department of Biology, Faculty of Mathematics and Natural Sciences, Universitas Sebelas Maret. Jl. Ir. Sutami 36A Surakarta 57126, Central Java, \\ Indonesia. Tel. Fax.: +62-271-663375, `email: agungbudiharjo@staff.uns.ac.id
}

Manuscript received: 11 July 2020. Revision accepted: 10 September 2020.

\begin{abstract}
Iriansyah AH, Budiharjo A, Sugiyarto. 2020. Parasites prevalence infecting freshwater fishes in Mulur Reservoir of Sukoharjo District, Indonesia. Bonorowo Wetlands 10: 92-97. Mulur Reservoir is one of the natural fish habitats and consumption fish cultivation in Sukoharjo District, Indonesia. Excessive use of the reservoir area causes decreased water quality, affecting fish life sustainability; one of them can cause the fish susceptibility to infection by parasites. This research aimed to identify the types of parasites that infect the consumption of fish in Mulur Reservoir and calculate the prevalence value. Samples were taken by purposive sampling for gourami (Osphronemus goramy), tilapia (Oreochromis niloticus), betutu fish (Oxyeleotris marmorata), catfish (Clarias batrachus), and jambal (Pangasius djambal) 10 fishes for each type. The parts of fish infected by ectoparasites such as body mucus, fin mucus, head mucus, and gills were taken by scrapping and observed under a microscope with magnification between 100-400x. The results showed that 5 types of ectoparasites were Epistylis sp., Ichthyophthirius multifilis, Trichodina sp., Dactylogyrus sp., and Gyrodactylus sp. with an average prevalence of more than 50\%. There are more ectoparasites in domesticated fish than in wild fish.
\end{abstract}

Keywords: Ectoparasites, freshwater fish, consumption fish, Mulur Reservoir Sukoharjo

\section{INTRODUCTION}

Sukoharjo District, Central Java, Indonesia, is one area that develops inland aquaculture. Inland fishery production in Sukoharjo has increased yearly, both in public waters, aquaculture with ponds, and cages. Mulur Reservoir, located in Mulur Village, Bendosari Sub-district, Sukoharjo District, is a freshwater ecosystem as a natural habitat for various types of fish. Its primary function is to irrigate agricultural areas, and besides that, it is also used as a means of fisheries management (Faradiana et al., 2018).

The fishery business carried out in the Mulur reservoir is divided into two types, namely fish caught and fish cultivated through cages. Both types of fish live in the same waters and environment. If there is a change in the environment, it will affect the survival of both of them, likewise with the presence of parasitic infections in fish. Factors affecting fish distribution include DO, water flow velocity, and food sources (Muchlisin and Azizah 2009).

Parasites are organisms that live on the bodies of other organisms and generally hurt the host organism. Parasites in fish can be divided into two types, namely ectoparasites and endoparasites. Ectoparasites are parasites that live on the outer surface of the host's body and in the hosts' skin burrows (Azmi 2013). Endoparasites live in internal organs such as the digestive system, liver, blood circulation, abdominal cavity, and other body tissues. Parasite attacks on fish cause fish to lose their appetite, then slowly weaken and lead to death. Clinical symptoms caused include spots on the fish that cause itching so that the fish will rub their bodies against objects around them, loss of appetite, and excessive mucus production (Kurniawan 2012).

Parasitism is a symbiosis in which one organism lives on the sacrifice of its host, both biochemically and physiologically (Anshary 2008). Parasites that infect fish, especially consumed fish, have not affected humans. However, these parasites will affect fish life, especially in metabolism. The energy from metabolism that should be used for growth must be used for energy protection or defense from these parasites. Fish infected by parasites are likely to impact the appearance of the fish, such as slow growth, small fish size, and damage to specific organs.

Knowledge of parasites in waters needs to be known as information about the ecology of parasites and their hosts in these waters. Research on parasites that infect fish, especially in the Mulur Reservoir, has never been done before, so there is no scientific information on this matter; therefore, it is important to research to identify the types of ectoparasites that attack fish in these waters and the prevalence of ectoparasites to determine the level of parasitic infection that can cause infection occurs in consumption fish. 


\section{MATERIALS AND METHODS}

The study was conducted from November 2018 to January 2019. Fish sampling was carried out in Mulur Reservoir, Mulur Village, Bendosari Sub-district, Sukoharjo District, Central Java Province, Indonesia. Parasite examination and identification were carried out at the Biology Laboratory, Faculty of Mathematics and Natural Sciences, Sebelas Maret University, Surakarta, Indonesia.

The tools used in this study were object-glass, cover glass, light microscope, surgical instruments (tweezers, scalpel, scissors), dropper, cooler box, paraffin tub, stationery, ruler, camera, and tools to measure water quality such as a thermometer, $\mathrm{pH}$ meter, DO meter, and Secchi disk.

The materials used in this study were distilled water and fish samples, namely goramy (Osphronemus goramy), tilapia (Oreochromis niloticus), marble goby fish (Oxyeleotris marmorata), catfish (Clarias batrachus), and pangas catfish (Pangasius djambal) taken from Mulur Reservoir as many as 10 individuals from each fish species. The fish samples obtained were identified using the identification book by Kottelat et al. (1993) and Saanin (1984). Sampling was carried out six times using the purposive sampling method at three predetermined points. The samples were fish that live wild in reservoirs and fish cultivated in floating net cages.

Examination of ectoparasites was carried out using macroscopic and microscopic. The macroscopic study is carried out by examining the presence or absence of clinical symptoms of parasites on the outside of the fish body, while the microscopic examination is by scrapping the surface of the body, head, fins, tail, and gills and then observed under a microscope with a magnification of 100400x. Examination of the gills was carried out by opening the operculum and then cutting the fish gill lamellae using scissors, placing it on a glass object, dripping with distilled water, then observing it under a microscope with a magnification of 100-400x.

Each parasite found on ectoparasite examination was recorded and collected for further identification. Identification of ectoparasites using the Kabata identification book (1985).

\section{Data analysis}

The results of a quantitative examination of ectoparasites were calculated using the formula according to Margolis et al. (1982) as follows:

$$
\begin{aligned}
& \text { Prevalence }=\frac{\sum \text { infected fish }}{\sum \text { sample fish }} \times 100 \% \\
& \text { Intensity }=\frac{\sum X \text { parasite found }}{\sum \text { sample infected by parasite } X}
\end{aligned}
$$

The identification of ectoparasites that attack consumption fish in the Mulur Reservoir was analyzed descriptively, and the data was presented in the form of images. The results of calculating the prevalence and intensity of ectoparasites obtained were analyzed descriptively quantitatively, and the data were presented in tabular form (Steel and Torrie 1993).

\section{RESULTS AND DISCUSSION}

Excessive use of reservoirs will affect the condition of these waters, especially for the survival of the fish that inhabit these waters. According to Tjokrokusumo (2008), differences in environmental conditions in the inlet and outlet areas result in variations in distribution patterns, behavior, and fish composition. The community's daily activities around the reservoir, such as residential areas and rice fields, can also affect the balance of the reservoir ecosystem.

According to PP No. 82 of 2001, waters suitable for use as freshwater fishery facilities are classified into second and third water classes with specific quality standards (Table 1). The condition of the waters of the Mulur Reservoir has water quality that is not under the quality standards specified in PP No. 82 of 2001, so it can be said that the waters are not suitable for fish life. Low oxygen levels can interfere with the respiratory process in fish, and low light penetration levels can interfere with the vision of some types of fish. The temperature and acidity of the water are still within the quality standard (Table 1).

\section{Types of ectoparasites}

The parasites found were Epistylis sp., Ichthyophthirius multifilis, Trichodina sp. (protozoa), Dactylogyrus sp., and Gyrodactylus sp. (monogenean).

\begin{tabular}{|c|c|c|c|c|c|c|}
\hline \multirow{2}{*}{ Variable } & \multirow{2}{*}{ Unit } & \multicolumn{3}{|c|}{ Sampling point } & \multirow[b]{2}{*}{ Average } & \multirow[b]{2}{*}{ Quality standards } \\
\hline & & 1 & 2 & 3 & & \\
\hline Temperature & ${ }^{\circ} \mathrm{C}$ & 30 & 30.7 & 32.3 & 31 & $26-32$ \\
\hline $\mathrm{pH}$ & & 8.5 & 7.9 & 7.9 & 8.1 & $6-9$ \\
\hline DO & $\mathrm{mg} / \mathrm{L}$ & 2.8 & 1.1 & 1.6 & 1.8 & $\geq 3$ \\
\hline Water clarity & $\mathrm{cm}$ & 26 & 27 & 28 & 27 & $\leq 10$ \\
\hline
\end{tabular}

Table 1. Abiotic environmental parameters of Mulur Reservoir, Sukoharjo District, Indonesia 


\section{Epistylis sp.}

Epistylis sp. is an ectoparasite of the type of protozoa with a bell-like morphology in the form of an elongated tube, translucent whitish in color. There is a small nucleus in its cells, and the cells can contract. Posteriorly there is a pair of cilia that look like stalks. Epistylis sp. is a protozoan measuring 45-250 m with a solitary life morphology, whitish in color, has a small macronucleus, does not contract, cells can contract, and has paired capsules (Irvansyah et al. 2012). An elongated zooid consists of a ciliated peristomial stalk, food vacuole, micronucleus, and macronucleus. These small protozoa have handles, usually in colonies composed of 2-5 individuals (Saglam and Sarieyyupoglu 2002). According to Andriyanto and Fachri (2014), this parasite is a parasite that primarily attacks freshwater fish and is generally from the Cyprinidae group and settles on the skin and fins of its host using cilia branches. This parasite has a protease enzyme secretion organ that is used to take protein from the host's skin (fish) to cause secondary infection by bacteria.

\section{Ichthyophthirius multifilis}

Ichthyophthirius multifilis is an ectoparasite of the type of protozoa with a round morphology, and there is a large macronucleus in its cells. Usually, these parasites lodge in the layers of the skin and fins and damage the epithelial tissue to cause bleeding. I. multifilis clusters in large numbers to form white spots on fish, so it is called white spot disease. I. multifilis has a round body shape where the whole body is ciliated and moves amoeba-like; inside the body, there is a transparent horseshoe-shaped macronucleus and a micronucleus attached to the macronucleus. This parasite is the most virulent protozoan parasite in fish (Nofyan et al., 2015; Rahmi. 2012).

\section{Trichodina sp.}

Trichodina sp. is an ectoparasite from the protozoa group with a transparent circular shape resembling a cup or wheel with several cilia surrounding the cell. At the center, there are three concentric circles called the adhesive plate. Trichodina sp. is a parasitic protozoa from the ciliates group with vibrating feathers. Trichodina sp. is a circular shape like a cup measuring 50-100 $\mathrm{m}$ with vibrating hairs strung on both sides of the cell (Irianto 2005).

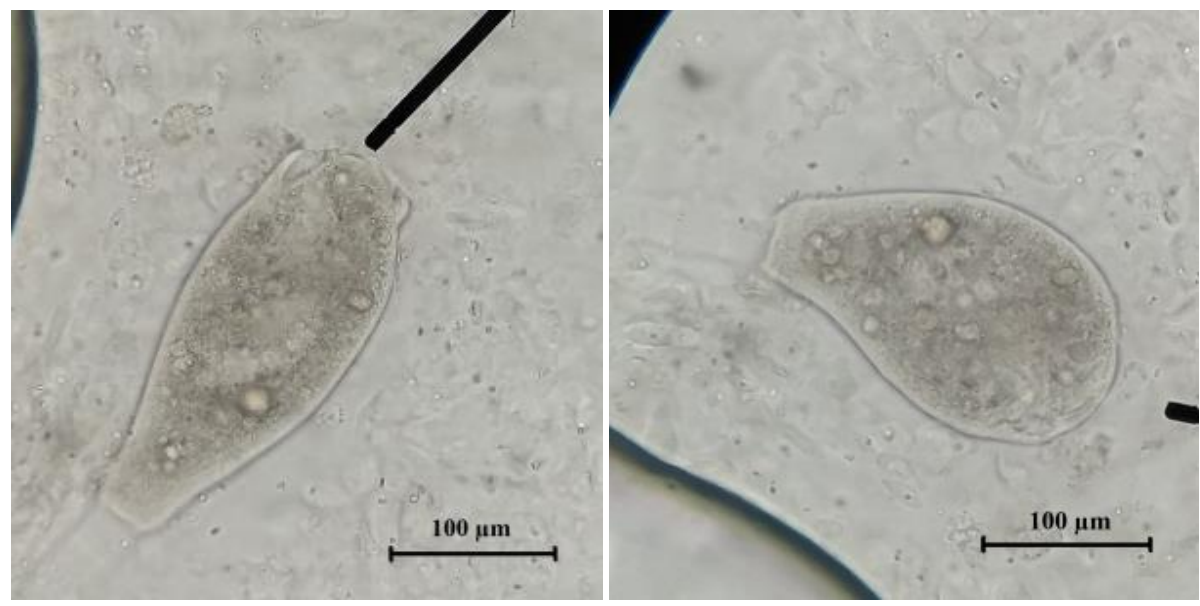

Figure 1. Epistylis sp. with a magnification of 100x
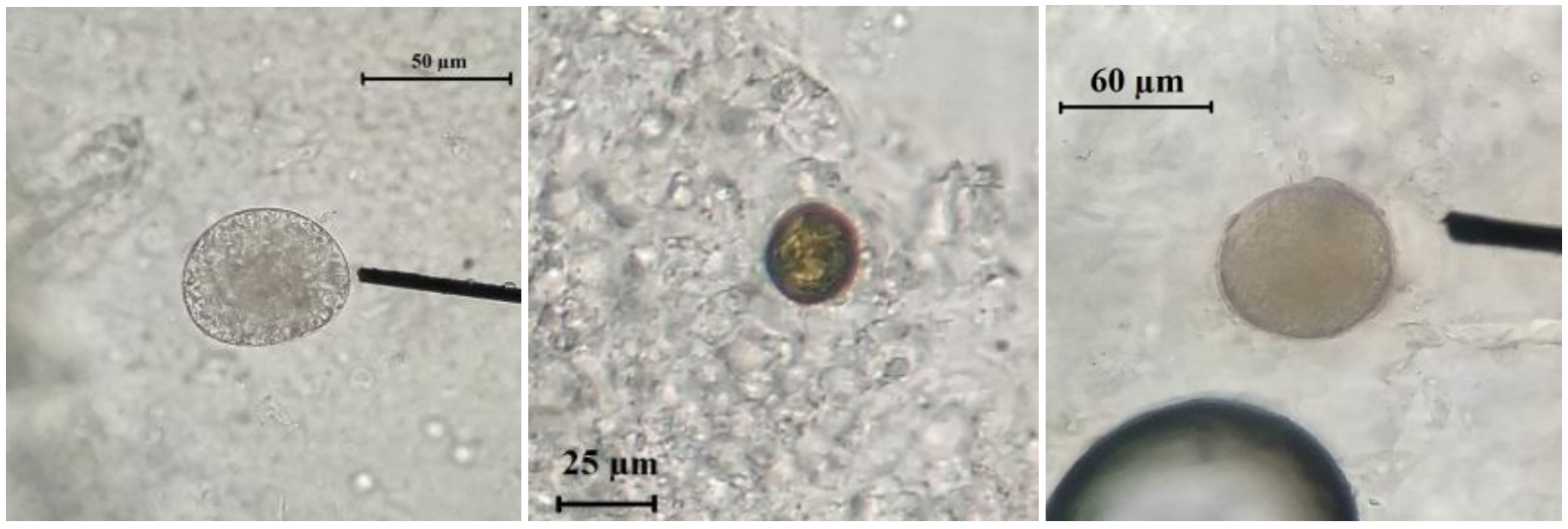

Figure 2. Ichthyophthirius multifilis with a magnification of 400x 

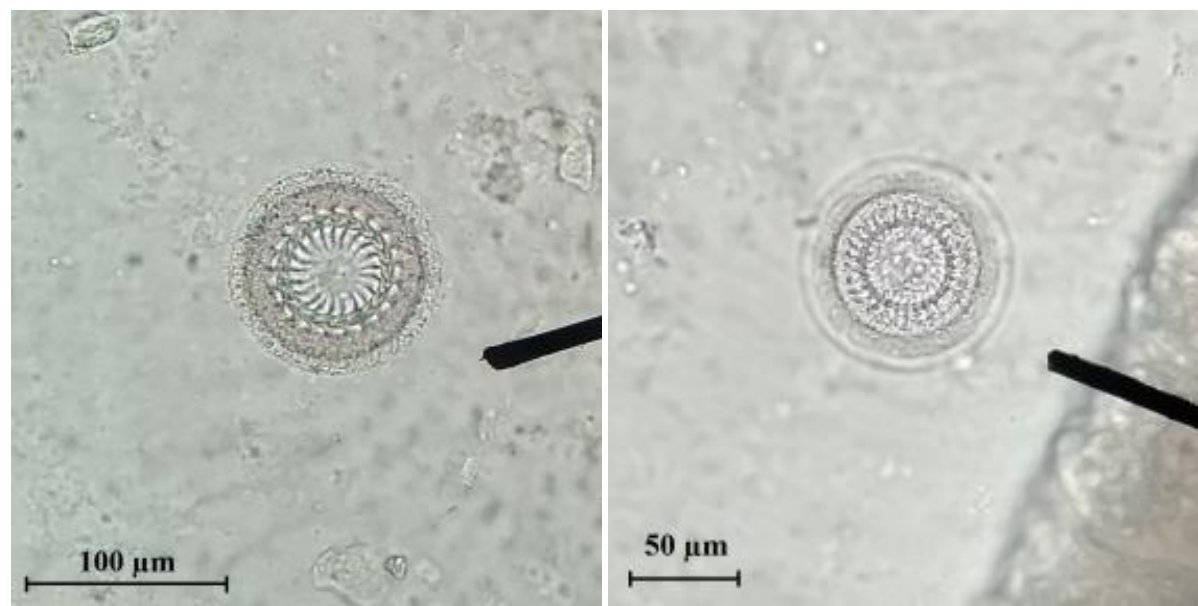

Figure 3. Trichodina sp. with a magnification of 400x
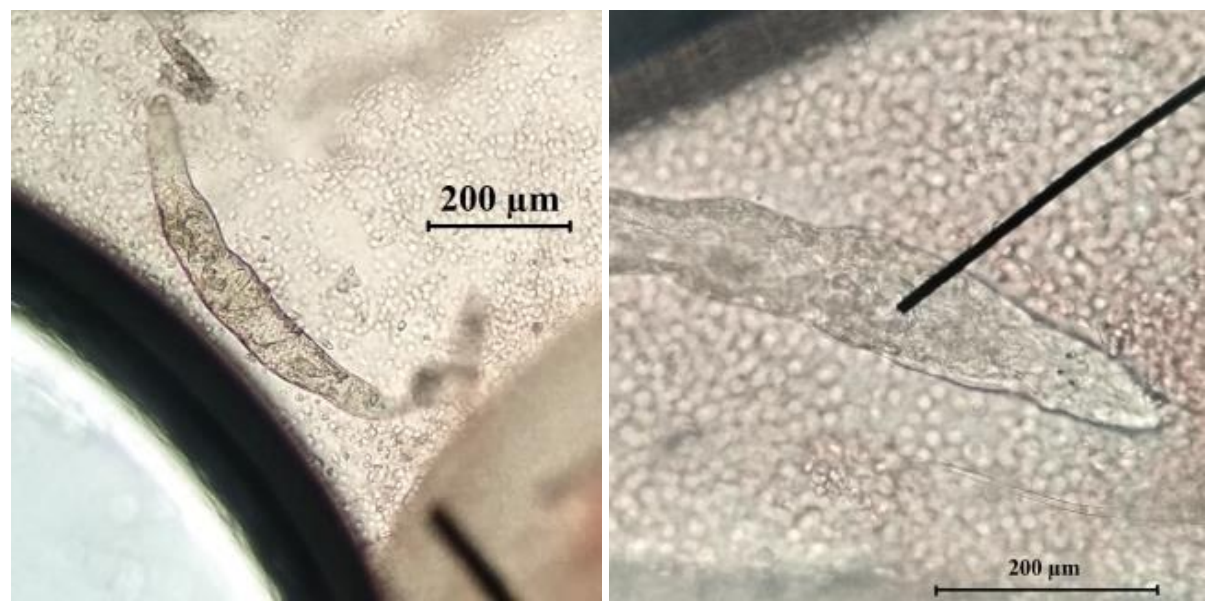

Figure 4. Dactylogyrus sp. with magnification of 100x and 400x
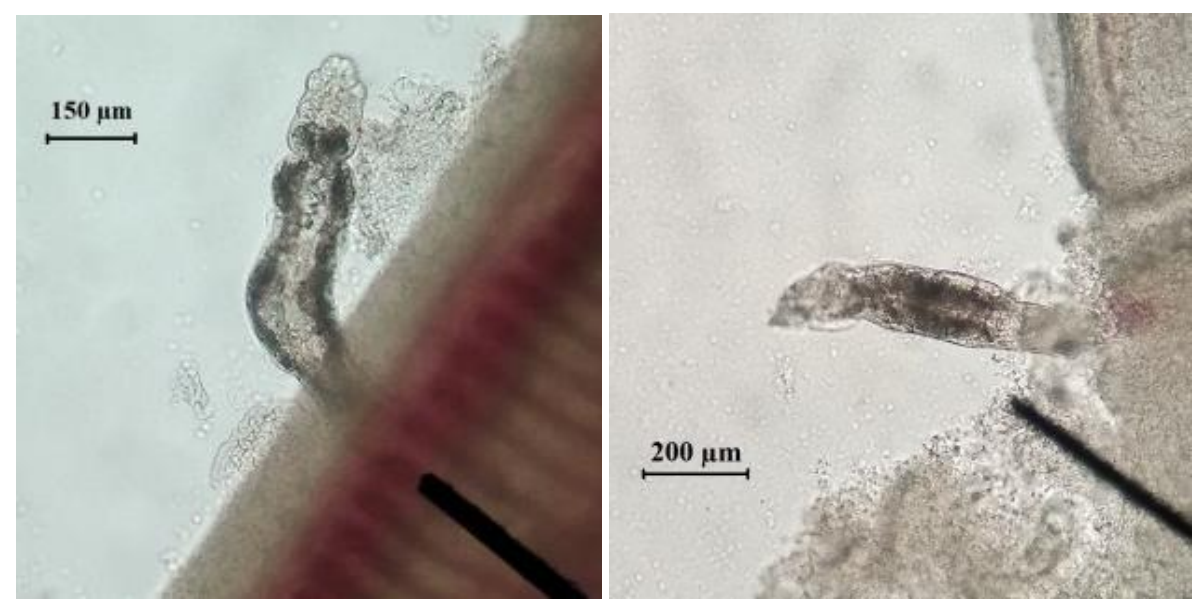

Figure 5. Gyrodactylus sp. with a magnification of 100x

\section{Dactylogyrus sp.}

Dactylogyrus sp. is an ectoparasite of the monogenean trematode worm group with an elongated, transparent shape with a smaller anterior end. This ectoparasite can be easily recognized by the presence of two pairs of eyespots

on the anterior end of its body. The mouth is located near the anterior end of the body, with the digestive tract towards the posterior. At the posterior end of the body, an attachment apparatus consists of two pairs of large hooks surrounded by smaller hooks called opisthaptors. 


\section{Gyrodactylus sp.}

Gyrodactylus sp. is an ectoparasite of the monogenean trematode worm group. Elongated transparent cylindrical parasite with a $\mathrm{V}$-shaped anterior end, 2 protrusions or lobes, without eyespots or eyespots as in Dactylogyrus sp. This parasite has a hook-shaped anchor on the posterior, surrounded by marginal hooks that attach to the host's body tissues, namely the skin and gills.

\section{Ectoparasite prevalence and intensity}

Ichthyophthirius multifilis is the most dominant parasite because this ectoparasite infection occurs evenly in the waters, evidenced by the parasite's presence in all fish samples. Ichthyophthirius multifilis is also referred to as a cosmopolitan ectoparasite because it can attack almost all types of freshwater fish. Still, it is also generally found in all kinds of freshwater ecosystems.

Some parasites are only found in certain types of fish. Trichodina sp. is a parasite that attacks tilapia and pangas catfish. The attack of this parasite on both fish occurred with a prevalence value of $100 \%$ and a relatively high intensity, but no Trichodina sp. attack was found. In other types of fish. Likewise, Epistylis sp. was found to attack only goramy and tilapia in the least amount. Dactylogyrus sp. attacks catfish and pangas catfish, and Gyrodactylus sp. attacks tilapia and pangas catfish.

Epistylis sp. found attacking the outer surface of the body, Ichthyophthirius multifilis and Trichodina sp. found attacking the outer surface of the body and gills, Dactylogyrus sp. found attacking the gills, and Gyrodactylus sp. found attacking the gills. Species influence differences in the distribution of ectoparasites in fish body parts.

The results showed that domesticated fish were more affected by ectoparasites than wild fish, both in terms of the type and number of infections. It can happen because fish outside the cage has a place to live with a broader range so that if an infection occurs in one fish, the risk of spreading that will happen is relatively low. In contrast to domesticated fish, if an infection occurs in one fish, the risk of spreading the parasite infection is somewhat higher, supported by physical contact between one fish and another.

Table 2. Ectoparasite Prevalence and Intensity in Mulur Reservoir Sukoharjo

\begin{tabular}{|c|c|c|c|c|c|c|c|}
\hline Type of fish & Source & Type of ectoparasites & $\Sigma$ Parasite & $\begin{array}{l}\Sigma \text { Infected } \\
\text { sample }\end{array}$ & $\begin{array}{l}\Sigma \text { Sample } \\
\text { observed }\end{array}$ & $\begin{array}{l}\text { Prevalence } \\
(\%)\end{array}$ & $\begin{array}{l}\text { Intensity } \\
\text { (parasite / fish) }\end{array}$ \\
\hline Goramy & $\begin{array}{l}\text { Domesticated } \\
\text { Average } \\
\text { Wild } \\
\text { Average }\end{array}$ & $\begin{array}{l}\text { Epistylis } \mathrm{sp} . \\
\text { I. multifilis }\end{array}$ & $\begin{array}{l}5 \\
23\end{array}$ & $\begin{array}{l}3 \\
8\end{array}$ & 10 & $\begin{array}{l}30 \\
80 \\
55\end{array}$ & $\begin{array}{l}1.67 \\
2.87 \\
\mathbf{2 . 2 7}\end{array}$ \\
\hline Tilapia & $\begin{array}{l}\text { Average } \\
\text { Wild } \\
\text { Average }\end{array}$ & $\begin{array}{l}\text { Trichodina } \mathrm{sp} . \\
\text { I. multifilis } \\
\text { Epistylis } \mathrm{sp} \text {. } \\
\text { Gyrodactylus } \mathrm{sp} \text {. } \\
\text { Trichodina } \mathrm{sp} . \\
\text { I. } \text { multifilis }\end{array}$ & $\begin{array}{l}151 \\
11 \\
1 \\
1 \\
89 \\
5\end{array}$ & $\begin{array}{l}5 \\
3 \\
1 \\
1\end{array}$ & 5 & $\begin{array}{l}100 \\
60 \\
20 \\
20 \\
\mathbf{5 0} \\
100 \\
40 \\
\mathbf{7 0}\end{array}$ & $\begin{array}{l}30.2 \\
3.67 \\
1 \\
1 \\
\mathbf{8 . 9 6} \\
17.8 \\
2.5 \\
\mathbf{1 0 . 1 5}\end{array}$ \\
\hline Marble goby & $\begin{array}{l}\text { Domesticated } \\
\text { Average } \\
\text { Wild } \\
\text { Average }\end{array}$ & I. multifilis & 32 & 9 & $\begin{array}{l}0 \\
10\end{array}$ & $\begin{array}{l}90 \\
90\end{array}$ & $\begin{array}{l}3.56 \\
\mathbf{3 . 5 6}\end{array}$ \\
\hline Catfish & $\begin{array}{l}\text { Domesticated } \\
\text { Average } \\
\text { Wild } \\
\text { Average }\end{array}$ & $\begin{array}{l}\text { I. multifilis } \\
\text { Dactylogyrus sp. } \\
\text { I. multifilis }\end{array}$ & $\begin{array}{l}13 \\
1 \\
6\end{array}$ & $\begin{array}{l}4 \\
1\end{array}$ & 5 & $\begin{array}{l}80 \\
20 \\
\mathbf{5 0} \\
60 \\
\mathbf{6 0}\end{array}$ & $\begin{array}{l}3.25 \\
1 \\
2.12 \\
2 \\
2\end{array}$ \\
\hline Pangas catfish & $\begin{array}{l}\text { Domesticated } \\
\text { Average } \\
\text { Wild }\end{array}$ & $\begin{array}{l}\text { Gyrodactylus sp. } \\
\text { Dactylogyrus sp. } \\
\text { I. multifilis } \\
\text { Trichodina sp. } \\
\\
\text { Dactylogyrus sp. } \\
\text { I. multifilis } \\
\text { Trichodina sp. }\end{array}$ & $\begin{array}{l}2 \\
13 \\
8 \\
182\end{array}$ & $\begin{array}{l}1 \\
4 \\
2 \\
5\end{array}$ & 5 & $\begin{array}{l}20 \\
80 \\
40 \\
100 \\
60 \\
20 \\
60 \\
100 \\
60\end{array}$ & $\begin{array}{l}2 \\
3.25 \\
4 \\
36.4 \\
\mathbf{1 1 . 4 1} \\
1 \\
4 \\
8.8 \\
\mathbf{4 . 6}\end{array}$ \\
\hline
\end{tabular}


Perbandingan Infeksi Parasit

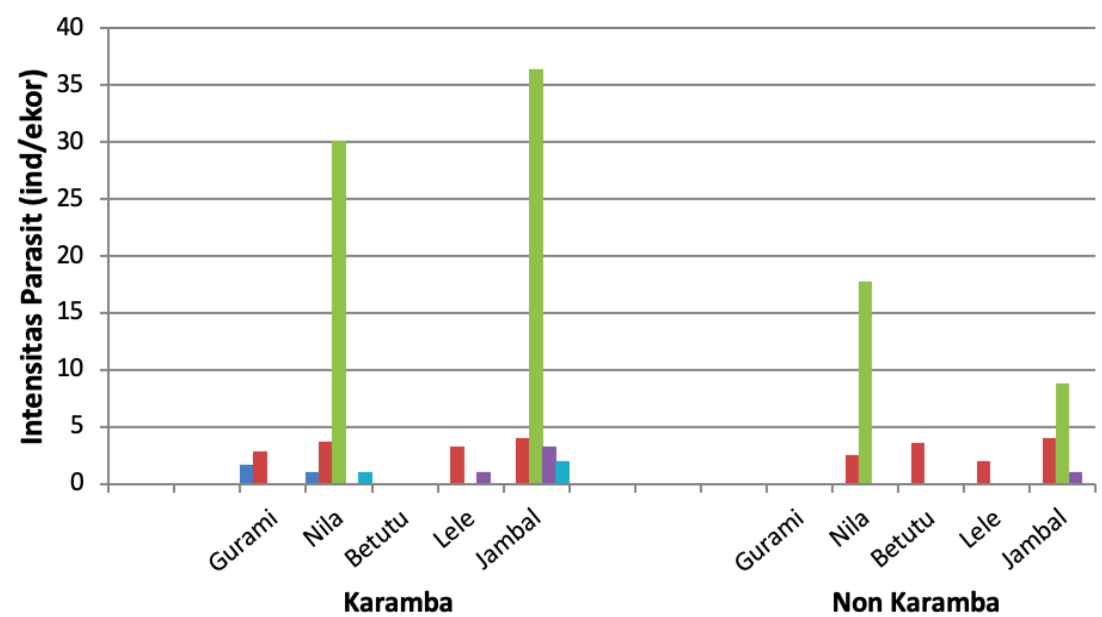

$\square$ Epistylis sp. $\quad$ I. multifilis $\quad$ Trichodina sp. $\quad$ Dactylogyrus sp. $\quad$ Gyrodactylus sp.

Figure 6. Comparison of parasite infections based on sampling locations

This study concludes that the types of ectoparasites that attack freshwater fish species in the Mulur reservoir are Epistylis sp., Ichthyophthirius multifilis, Trichodina sp., Dactylogyrus sp., and Gyrodactylus sp. The average prevalence rate of ectoparasites by type of fish, in goramy, is $55 \%$; in domesticated tilapia by $50 \%$; in wild tilapia by $70 \%$; in marble goby fish by $90 \%$; in domesticated catfish by $50 \%$; in wild catfish by $60 \%$; in domesticated pangas catfish by $60 \%$; and wild pangas catfish by $60 \%$.

\section{REFERENCES}

Andriyanto S, Fachri M. 2014. Keberadaan ektoparasit pada ikan mas (Cyprinus carpio) yang dipelihara dengan perbedaan persentase pergantian air. Media Akuakultur 9 (2): 111-118. [Indonesian]

Anshary. 2008. Tingkat infeksi parasit pada ikan mas koi (Cyprinus carpio) pada beberapa lokasi budidaya ikan hias di Makassar dan Gowa. Jaringan Sains dan Teknologi 8 (2): 139-147. [Indonesian]

Azmi H, Indriyanti DR, Kariada N. 2013. Identifikasi ektoparasit pada ikan koi (Cyprinus carpio L) di pasar ikan hias Jurnatan Semarang. Life Sci 2 (2): 64-70. [Indonesian]

Faradiana R, Budiharjo A, Sugiyarto S. 2018. Keanekaragaman dan pengelompokan jenis ikan di Waduk Mulur Sukoharjo, Jawa Tengah, Indonesia. DEPIK Jurnal Ilmu-Ilmu Perairan, Pesisir dan Perikanan 7 (2): 151-163. DOI: 10.13170/depik.7.2.10004. [Indonesian]

Fatah K, Adjie S. 2013. Biologi reproduksi ikan betutu (Oxyeleotris marmorata) di Waduk Kedungombo Propinsi Jawa Tengah. BAWAL 5 (2): 89-96. [Indonesian]

Irianto A. 2005. Patologi Ikan Teleostei. Gadjah Mada University Press, Yogyakarta. [Indonesian]

Irvansyah MY, Aldulgani N, Mahasri G. 2012. Identifikasi dan intensitas ektoparasit pada kepiting bakau (Scylla serrata) stadia kepiting muda di pertambakan kepiting, Kecamatan Sedati, Kabupaten Sidoarjo. Sains Seni ITS 1 (1): 1-5. [Indonesian]

Kabata Z. 1985. Parasites and Diseases of Fish Cultured in the Tropic. Taylor dan Prancis, London.
Klinger R, Floyd RF. 2013. Introduction to Freshwater Fish Parasites. University of Florida Press, Florida.

Kottelat M, Whitten AJ, Kartikasari SN, Wirjoatmodjo S. 1993. Ikan Air Tawar Indonesia Bagian Barat dan Sulawesi. Periplus, Jakarta. [Indonesian]

Margolis L, Esch GW, Holmes JC, Kuris AM, Shad GA. 1982. The use of ecological terms in parasitology (Report of an Ad Hoc Committee of the American Society of Parasitologists). J Parasitol 68 (1): 131-133. DOI: $10.2307 / 3281335$

Muchlisin A, Azizah MNS. 2009. Diversity and distribution of freshwater fishes in Aceh Water, Northern Sumatra, Indonesia. Indon J Zool 5 (2): 62-79. DOI: 10.3923/ijzr.2009.62.79.

Nofyan E, Ridho MR, Fitri R. 2015. Identifikasi dan prevalensi ektoparasit dan endoparasit pada ikan nila (Oreochromis niloticus Linn) di kolam budidaya Palembang, Sumatera Selatan. SEMIRATA 4 (1). DOI: 10.35800/bdp.4.2.2016.13053. [Indonesian]

Pemerintah Republik Indonesia. 2001. Peraturan Pemerintah Republik Indonesia Nomor 82 Tahun 2001 Tentang Pengelolaan Kualitas Air dan Pengendalian Pencemaran. Kementrian Lingkungan Hidup, Jakarta. 10.2307/3281335. [Indonesian]

Purbomartono C. 2010. Identify of helminth and crustacean ectoparasites on Puntius javanicus fry at local hatchery center Sidabowa and Kutasari. Sains Akuatik 10 (2): 134-140.

Purwakusuma. 2007. Pengendalian Hama dan Penyakit Ikan. Kanisius, Yogyakarta. [Indonesian]

Rahmi. 2012. Identifikasi ektoparasit pada ikan nila (Oreochromis niloticus) yang dibudidayakan pada tambak Kabupaten Maros. Jurnal Ilmu Perikanan 1 (1): 19-23. [Indonesian]

Rukmana HR. 2005. Pembenihan dan Pembesaran Ikan Gurami. Kanisius, Yogyakarta.

Saanin H. 1984. Taksonomi dan Kunci Identifikasi Ikan. Bina Cipta, Jakarta. [Indonesian]

Saglam N, Sarieyyupoglu M. 2002. A study on Tetrahymena pyriformis (Holotrichous) and Epistylis sp. (Peritrichous) found on freshwater Leech, Nephelopsis obscura. Pak J Biol Sci 5 (4): 497-498. DOI: 10.3923/pjbs.2002.497.498.

Steel RGD, Torrie JH. 1993. Prinsip dan Prosedur Statistika (Pendekatan Biometrik). Gramedia Pustaka Utama, Jakarta. [Indonesian]

Tjokrokusumo SW. 2008. Pengaruh sedimentasi dan turbidity pada jenjang makanan ekosistem air mengalir (lotik). Jurnal Hidrosfir 3 (3): 137-148. [Indonesian] 